\title{
Polymorphic CAG repeats of the androgen receptor gene and rheumatoid arthritis
}

Taku Kawasaki, Toshio Ushiyama, Hisao Ueyama, Koji Inoue, Kanji Mori, Iwao Ohkubo, Sinsuke Hukuda
AR. ${ }^{8}$ More than double the average number of CAG repeats were found in the AR genes of patients with spinal and bulbar muscular atrophy associated with mild androgen insensitivity, and the AR in those patients had a reduced transactivation activity despite displaying normal androgen binding activity. ${ }^{9}$

In view of the possible role of androgens in developing RA and the importance of genetic factors in RA, we investigated the relation between the CAG microsatellite repeat lengths of the AR gene and RA.

\section{Methods}

SUBJECTS

A total series of 367 consecutive patients with RA, who visited our outpatient clinic between October 1996 and April 1998, were studied. They all fulfilled the American College of Rheumatology 1987 criteria. $^{10}$ Ninety were men and 277 were women. The clinical features of the patients, such as age at onset, seropositivity, and the presence of nodules, were recorded. Determination of the age at onset was based on the patient's recollection. Peripheral blood was collected for the analysis of AR gene polymorphisms. The blood samples of 641 controls ( 306 men and 335 women) that underwent an annual health care check held by several communities were also analysed.

\section{ANALYSIS OF CAG REPEATS OF THE AR GENE}

Analysis of CAG repeats of the AR gene was performed according to the method previously reported $^{11}$ with a slight modification. Briefly, $100 \mathrm{ng}$ of genomic DNA, extracted from peripheral blood, was amplified by two rounds of a polymerase chain reaction (PCR) in a series using nested primers surrounding the CAG repeat in exon 1 of the AR gene. Instead of autoradiography using radiolabelled dCTP in the second PCR, the final products, electrophoresed in $6 \%$ denaturing gels, were visualised by the silver staining method. To determine the number of CAG repeats, all of the final products of different sizes were sequenced using the ABI 310 sequencer (Perkin Elmer, CA, USA) according to the manufacturer's instructions.

Medical Biochemistry, Shiga University of Medical Science, Seta, Otsu, Japan

H Ueyama

I Ohkubo

Correspondence to: Dr T Kawasaki.
The role of androgens in the pathogenesis of rheumatoid arthritis (RA) has been suggested an aetiological role of lower serum testosterone levels in developing RA. ${ }^{1}$ Genetic association in RA is well recognised, ${ }^{5}$ and evidence suggests a linkage between testosterone levels and MHC in both mice and humans. ${ }^{67}$

Tissue response to androgen is determined by the androgen receptor (AR), which is located in chromosome $\mathrm{X}$, and activates the expression of other genes. This regulatory activity resides in the $\mathrm{NH} 2$ terminal domain of the protein, encoded by exon 1 . Recent studies have shown that this exon contains a polymorphic CAG repeat sequence that normally ranges from approximately 8 to 31 repeats. In vitro, the length of the CAG repeats correlates inversely with transcriptional activity by the discussed. ${ }^{1-4}$ In men, a number of studies have
STATISTICAL ANALYSIS

Student's $t$ test was used when the number of CAG repeats was compared between two groups. For the analysis of relative risk, an odds ratio (OR), 95\% confidence intervals (CI), and $\mathrm{p}$ value were calculated. The software application used for the analysis was SPSS (SPSS Inc, Chicago, USA). 
Table 1 Frequency distribution and mean values of $C A G$ repeat lengths in $R A$ patients and control subjects

\begin{tabular}{|c|c|c|c|c|}
\hline \multirow[b]{2}{*}{$\begin{array}{l}\text { Number of } \\
\text { CAG repeats }\end{array}$} & \multicolumn{2}{|l|}{ Men } & \multicolumn{2}{|l|}{ Women } \\
\hline & $\begin{array}{l}\text { Controls ( } 305 \text { alleles) } \\
\text { Number (\%) }\end{array}$ & $\begin{array}{l}\text { RA (90 alleles) } \\
\text { Number (\%) }\end{array}$ & $\begin{array}{l}\text { Controls (664 alleles) } \\
\text { Number }(\%)\end{array}$ & $\begin{array}{l}\text { RA (552 alleles) } \\
\text { Number (\%) }\end{array}$ \\
\hline 12 & $0(0.0)$ & $1(1.1)$ & $2(0.3)$ & $4(0.7)$ \\
\hline 13 & $0(0.0)$ & $1(1.1)$ & $1(0.2)$ & $0(0.0)$ \\
\hline 14 & $1(0.3)$ & $0(0.0)$ & $1(0.2)$ & $0(0.0)$ \\
\hline 15 & $0(0.0)$ & $1(1.1)$ & $1(0.2)$ & $2(0.4)$ \\
\hline 16 & $2(0.7)$ & $0(0.0)$ & $1(0.2)$ & $4(0.7)$ \\
\hline 17 & $3(1.0)$ & $2(2.2)$ & $14(2.1)$ & $8(1.4)$ \\
\hline 18 & $4(1.3)$ & $1(1.1)$ & $9(1.4)$ & $11(2.0)$ \\
\hline 19 & $15(4.9)$ & $4(4.4)$ & $31(4.7)$ & $36(6.3)$ \\
\hline 20 & $20(6.6)$ & $10(11.1)$ & $50(7.5)$ & $37(6.5)$ \\
\hline 21 & $46(15.1)$ & $14(15.6)$ & $103(15.5)$ & 75 (13.8) \\
\hline 22 & $46(15.1)$ & $10(11.1)$ & $82(12.3)$ & $76(13.6)$ \\
\hline 23 & $57(18.7)$ & $11(12.2)$ & $110(16.6)$ & $110(19.9)$ \\
\hline 24 & $22(7.2)$ & $12(13.3)$ & $89(13.4)$ & $62(11.2)$ \\
\hline 25 & $27(8.9)$ & $10(11.1)$ & $54(8.1)$ & $44(8.0)$ \\
\hline 26 & $22(7.2)$ & $6(6.7)$ & $43(6.5)$ & $39(7.1)$ \\
\hline 27 & $17(5.6)$ & $4(4.4)$ & $34(5.1)$ & $18(3.3)$ \\
\hline 28 & $6(2.0)$ & $2(2.2)$ & $21(3.2)$ & $18(3.3)$ \\
\hline 29 & $9(3.0)$ & $0(0.0)$ & $10(1.5)$ & $7(1.3)$ \\
\hline 30 & $1(0.3)$ & $1(1.1)$ & $5(0.8)$ & $3(0.5)$ \\
\hline 31 & $2(0.7)$ & $0(0.0)$ & $3(0.5)$ & $0(0.0)$ \\
\hline 32 & $5(1.6)$ & $0(0.0)$ & $0(0.0)$ & $0(0.0)$ \\
\hline Mean & 23.1 & 22.5 & 22.9 & 22.7 \\
\hline $\begin{array}{l}95 \% \mathrm{CI} \text { for } \\
\text { difference }\end{array}$ & $-0.04,1.37$ & & $-009,0.54$ & \\
\hline $\mathrm{p}$ value & 0.07 & & 0.17 & \\
\hline
\end{tabular}

\section{Results}

CLINICAL CHARACTERISTICS OF RA PATIENTS

The number of CAG repeats of the AR gene could not be identified in one female and one male RA patient, or in three female controls. As a result, 90 male and 276 female RA patients, and 305 male and 332 female controls were included in the study. Ages of RA patients at presentation ranged from 22 to 82 (mean 60.1) for men and from 25 to 85 (mean 56.5) for women. The age at onset of RA was from 18 to 82 (mean 51.6) for men and from 17 to 81 (mean 45.0) for women, the difference between both sexes being significant $(p<0.001)$.

Table 2 Frequency distribution and mean values of $C A G$ repeat lengths in $R A$ patients by onset age group and sex

\begin{tabular}{|c|c|c|c|c|}
\hline \multirow[b]{3}{*}{$\begin{array}{l}\text { Number of } \\
\text { CAG repeats }\end{array}$} & \multicolumn{2}{|l|}{ Men $R A$} & \multicolumn{2}{|l|}{ Women RA } \\
\hline & \multicolumn{2}{|l|}{ age at onset } & \multicolumn{2}{|l|}{ age at onset } \\
\hline & $\begin{array}{l}<55 \text { y (46 alleles) } \\
\text { Number (\%) }\end{array}$ & $\begin{array}{l}\geqslant 55 \text { y (44 alleles) } \\
\text { Number (\%) }\end{array}$ & $\begin{array}{l}<46 \text { y (278 alleles) } \\
\text { Number (\%) }\end{array}$ & $\begin{array}{l}\geqslant 46 \text { y ( } 274 \text { alleles }) \\
\text { Number }(\%)\end{array}$ \\
\hline 12 & $1(2.2)$ & $0(0.0)$ & $2(0.7)$ & $2(0.7)$ \\
\hline 13 & $1(2.2)$ & $0(0.0)$ & $0(0.0)$ & $0(0.0)$ \\
\hline 14 & $0(0.0)$ & $0(0.0)$ & $0(0.0)$ & $0(0.0)$ \\
\hline 15 & $1(2.2)$ & $0(0.0)$ & $2(0.7)$ & $0(0.0)$ \\
\hline 16 & $0(0.0)$ & $0(0.0)$ & $1(0.4)$ & $3(1.1)$ \\
\hline 17 & $2(4.3)$ & $0(0.0)$ & $6(2.2)$ & $2(0.7)$ \\
\hline 18 & $0(0.0)$ & $1(2.3)$ & $4(1.4)$ & $7(2.6)$ \\
\hline 19 & $3(6.5)$ & $1(2.3)$ & $18(6.5)$ & $17(6.2)$ \\
\hline 20 & $6(13.0)$ & $4(9.1)$ & $20(7.2)$ & $16(5.8)$ \\
\hline 21 & $6(13.0)$ & $8(18.2)$ & $39(14.0)$ & $37(13.5)$ \\
\hline 22 & $7(15.2)$ & $3(6.8)$ & $38(13.7)$ & $37(13.5)$ \\
\hline 23 & $3(6.5)$ & $8(18.2)$ & $50(18.0)$ & $60(21.9)$ \\
\hline 24 & $7(15.2)$ & $5(11.4)$ & $28(10.1)$ & $34(12.4)$ \\
\hline 25 & $4(8.7)$ & $6(13.6)$ & $26(9.4)$ & $18(6.6)$ \\
\hline 26 & $3(6.5)$ & $3(6.8)$ & $19(6.8)$ & $20(7.3)$ \\
\hline 27 & $0(0.0)$ & $4(9.1)$ & $10(3.6)$ & $8(2.9)$ \\
\hline 28 & $1(2.2)$ & $1(2.3)$ & $10(3.6)$ & $8(2.9)$ \\
\hline 29 & $0(0.0)$ & $0(0.0)$ & $4(1.4)$ & $3(1.1)$ \\
\hline 30 & $1(2.2)$ & $0(0.0)$ & $1(0.4)$ & $2(0.7)$ \\
\hline 31 & $0(0.0)$ & $0(0.0)$ & $0(0.0)$ & $0(0.0)$ \\
\hline 32 & $0(0.0)$ & $0(0.0)$ & $0(0.0)$ & $0(0.0)$ \\
\hline Mean & 21.8 & 23.2 & 22.7 & 22.7 \\
\hline $\begin{array}{l}\text { 95\% } 1 \text { for } \\
\text { difference }\end{array}$ & $0.37,2.35$ & $-1.15,0.86$ & $-0.18,0.70$ & $-0.28,0.64$ \\
\hline $\mathrm{p}$ value & 0.007 & 0.77 & 0.25 & 0.43 \\
\hline
\end{tabular}

${ }^{\star}$ Compared with controls (same sex and same age range).
Serum rheumatoid factor positivity was $92.2 \%$ for men and $93.5 \%$ for women, while rheumatoid nodule positivity was $13.3 \%$ for men and $12.0 \%$ for women. The age of the controls was from 17 to 91 (mean 48.9) for men and from 20 to 87 (mean 43.6) for women.

CAG REPEATS OF THE AR GENE IN OVERALL RA

Because the AR gene is mapped to chromosome $\mathrm{X}$, men have one allele and women two. We therefore analysed 552 alleles in the female RA patients and 664 alleles in the female controls. Table 1 shows the frequency distribution of the number of CAG repeats and mean lengths of CAG repeats by sex. The male RA patients tended to have shorter CAG repeats than the male controls (mean 22.5 versus 23.1, $95 \% \mathrm{CI}$ for difference: $-0.04,1.37, \mathrm{p}=0.07$ ), whereas the female patients had similar CAG repeat lengths to the female controls (mean 22.7 versus $22.9,95 \% \mathrm{CI}$ for difference: -0.09 , $0.54, \mathrm{p}=0.17)$.

CAG REPEATS OF THE AR GENE IN YOUNGER AND OLDER ONSET GROUPS

The RA patients were divided into two groups, younger and older age at onset, with the median value of onset age chosen as the cut off point (55 years for male RA and 46 years for female RA patients). Male and female controls were also divided into younger and older groups with the same cut off point ( 55 years for men and 46 years for women). Table 2 shows the frequency distribution and the mean values of CAG repeat lengths by onset age group and sex. The younger onset male patients (onset age $<55$ ) had significantly shorter mean CAG repeat lengths compared with the younger male controls (mean 21.8 versus 23.2, 95\% CI for difference: $0.37,2.35, \mathrm{p}=0.007)$. The older onset male patients (onset age $\geqslant 55$ ) had similar lengths as compared with the older male controls (mean 23.2 versus $23.0,95 \%$ CI for difference: $-1.15,0.86, p=0.77)$. The mean number of CAG repeats was also statistically different between the younger onset and the older onset male patients (mean 21.8 versus 23.2, 95\% CI for difference: $0.64,2.60$, $\mathrm{p}=0.04)$. In women, there were no significant differences in repeat lengths between the younger onset (onset age $<46$ ) patients and the younger controls (mean 22.7 versus 22.9, $95 \% \mathrm{CI}$ for difference: $-0.18,0.70, \mathrm{p}=0.25$ ) or between the older onset (onset age $\geqslant 46$ ) patients and the older controls (mean 22.7 versus $22.9,95 \% \mathrm{CI}$ for difference: $-0.28,0.64$, $\mathrm{p}=0.43)$.

Notably, there were five patients with CAG repeat lengths of less than 18 in the younger onset male RA group, but none in the older onset male RA group (table 2). The OR of having shorter CAG repeats $(<18)$ among younger onset male RA patients was 6.08 versus the younger male controls $(95 \% \mathrm{CI}$ for difference: $1.77,20.81, \mathrm{p}=0.001$ ), although the selection of the cut off point (18 repeats) was not arbitrary.

Because women have two AR gene alleles, the mean lengths of the shorter and longer CAG repeats of the two were separately 
Table 3 Mean $C A G$ repeats by rheumatoid factor $(R F)$ positivity, rheumatoid nodule (RN) positivity and sex

\begin{tabular}{|c|c|c|c|c|}
\hline & \multicolumn{2}{|l|}{ Men $R A$} & \multicolumn{2}{|l|}{ Women $R A$} \\
\hline & $R F(+)$ & $R F(-)$ & $R F(+)$ & $R F(-)$ \\
\hline \multirow{5}{*}{$\begin{array}{l}\text { Number of subjects } \\
\text { Mean CAG repeats } \\
95 \% \text { CI for difference } \\
\text { p value }\end{array}$} & 83 & 7 & 258 & 18 \\
\hline & 22.6 & 21.6 & 22.7 & 22.2 \\
\hline & $-1.43,3.40$ & & $-0.39,1.50$ & \\
\hline & 0.42 & & 0.25 & \\
\hline & $R N(+)$ & $R N(-)$ & $R N(+)$ & $R N(-)$ \\
\hline Number of subjects & 12 & 78 & 33 & 243 \\
\hline Mean CAG repeats & 22.4 & 22.5 & 22.6 & 22.7 \\
\hline $95 \% \mathrm{C} 1$ for difference & $-1.98,1.84$ & & $-0.67,0.78$ & \\
\hline $\mathrm{p}$ value & 0.94 & & 0.88 & \\
\hline
\end{tabular}

compared between the overall, the younger onset and the older onset female patients, and their female controls. However, none of these analyses found any significant differences between the patient and the control groups (data not shown).

The mean CAG repeat lengths were compared between seropositive and seronegative patients, and between rheumatoid nodule positive and negative patients by sex. As table 3 shows, there was no significant relation between these clinical variables and CAG repeat lengths for either sex.

\section{Discussion}

This study showed a relation between shorter CAG repeat lengths of the AR gene and younger onset male RA. The results of this study are in contrast with our previous report that found that some variants of the oestrogen receptor gene are related to the age at onset of female RA patients. ${ }^{12}$

As reviewed by Cutolo and Masi, ${ }^{1-4}$ the evidence suggests that a physiological concentration of oestrogens stimulates immune response, while male hormones suppress it. The length of the polymorphic CAG repeats is considered to have an inverse relation with the transcriptional activity of the AR. ${ }^{8}$ Postulating that shorter CAG repeats evoke heightened androgenic stimulation, our results might contradict accumulating evidence showing that lower androgen levels are associated with RA.

At present, there are no known data regarding the interactions among $\mathrm{AR}$ CAG repeat lengths and serum androgen levels. However, one possible explanation would be that short form AR with other genetic factors leads to low levels of testosterone. In fact, cytochrome P450 17ahydroxylase/ C17-20 lyase (P450c17 $\alpha$ ), a key enzyme for androgen synthesis, is negatively regulated by testosterone through an AR mediated mechanism in Leidig cells. ${ }^{13}$ In addition, cytochrome P450 aromatase, an enzyme that convert androgen to oestrogen, is increased by testosterone through an AR mediated feed forward system. ${ }^{14}$ Increased transcriptional activity of short form AR might therefore reduce the serum testosterone levels.

The results of this study must be contrasted with those of prostatic cancer, in which shorter
CAG repeat lengths were found to be a significant risk factor for developing the disease. ${ }^{15}$ Shorter CAG repeat lengths $(\leqslant 18)$ of the AR are closely related to overall prostatic cancer, especially to an aggressive phenotype. ${ }^{16}$ In this study, short form AR $(<18)$ was related to younger male RA pateints. From these findings, it is possible to speculate that men having shorter CAG repeat lengths may tend to be subject to a pathological process in the androgen responsive cells.

There were no significant relations found between CAG repeat length and disease severity indexes, such as seropositivity and rheumatoid nodule positivity, in our male and female RA patients. However, the number of seronegative patients and those with nodules was too small to draw a definitive conclusion.

In summary, this study shows the possible role of variants of the androgen receptor as a modulating factor in male RA patients. However, the biological mechanism of the disease modulation should be further investigated.

1 Masi AT. Sex hormones and rheumatoid arthritis: cause and effect relationship in a complex patophysiology? Clin Exp Rheumatol 1995;13:227-40.

2 Cutolo M, Accardo S. Sex hormones, HLA and rheumatoid arthritis. Clin Exp Rheumatol 1991;9;641-6.

3 Cutolo M, Masi AT. Do androgens influence the pathophysiology of rheumatoid arthritis? Facts and hypothesis. J Rheumatol 1998;25:1041-7.

4 Cutolo M. Do sex hormones modulate the synovial macrophages in rheumatoid arthritis? Ann Rheum Dis 1997;56: $281-6$

5 Silman AJ, MacGregor AJ, Thomson W, Holligan S, Carthy $\mathrm{D}$, Farhan A, et al. Twin concordance rates for rheumatoid arthritis: results from a nationwide study. Br J Rheumatol 1993;32:903-7.

6 Ollier W, Spector T, Silman A, Perry L, Ord J, Thomson W, et al. Are certain HLA haplotypes responsible for low testosterone levels in males? Dis Markers 1989;7:139-43.

7 Ivanyi P, Hampl R, Starka L, Mickova M. Genetic association between $\mathrm{H}-2$ gene and testosterone metabolism in mice. Nature New Biol 1972;238:281-2

8 Chamberlain NL, Driver ED, Miesfeld RL. The length and location of CAG trinucleotide repeats in the androgen receptor N-terminal domain affect transactivation function. Nucleic Acids Res 1994;22:3181-6.

9 Mhatre AN, Trifiro MA, Kaufman M, Kazemi-Esfarjani P, Figlewicz D, Rouleau G, et al. Reduced transcriptional regulatory competence of the androgen receptor in $\mathrm{X}$-linked spinal and bulbar muscular atrophy. Nature Genet 1993;5:184-8.

10 Arnett FC, Edworthy SM, Bloch DA, McShane DJ, Fries JF, Cooper NS, et al. The American Rheumatism Association 1987 revised criteria for the classification of rheumatoid arthritis. Arthritis Rheum 1988;31:315-24.

11 Irvine RA, Yu MC, Ross RK, CoetzeeGA. The CAG and GGC microsatellites of the androgen receptor gene are in linkage disequilibrium in men with prostate cancer. Cancer Res 1995;55:1937-40.

12 Ushiyama T, Mori K, Inoue K, J Huang, J Noshioka, Hukuda S. Asociation of estrogen receptor gene polymorphisms with age at onset of rheumatoid arthritis. Ann Rheum Dis 1999;58:7-10.

13 Payne AH. Hormonal regulation of cytochrome P450 enzymes, cholesterol side-chain cleavage and 17a hydroxylase/C17-20 lyase in Leydig cells. Biol Reprod hydroxylase/C17-20

14 Roselli CE, Resko JA. Sex differences in androgen-regulated expression of cytochrome $\mathrm{P} 450$ aromatase in the rat brain J Steroid Biochem Mol Biol 1997;61:365-74.

15 Stanford JL, Just JJ, Gibbs M, Wicklund KG, Neal CL, Blumenstein BA, et al. Polymorphic repeats in the androgen receptor gene: Molecular markers of prostate cancer risk. receptor gene: Molecular mark

16 Giovannucci E, Stampfer M, Krithivas K, Brown M, Brufsky A, Talcott J, et al. The CAG repeat within the androgen receptor gene and its relationship to prostate cancer. Proc Natl Acad Sci USA 1997;94:3320-3. 